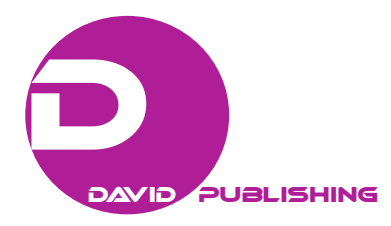

\title{
The Use of Smart Technology in Tourism: Evidence From Wearable Devices*
}

\author{
Roland Atembe \\ University of Innsbruck, Republic of Austria
}

\begin{abstract}
The emergence of wearable devices has shifted internet from the conventional cyber space to becoming wearable on the body. This new paradigm shift has precipitated a lot of speculations about its impact on the tourism industry. Access to wearable web is predicted to drastically streamline the way tourists connect with stakeholders and the environment around them. Although it is relatively new, wearable technological devices are predicted to have a significant effect on people's interaction. However, research describing the application of wearable devices in tourism is relatively lacking in academic literature. This paper examines the usage of wearable devices in tourism. The essay aims at contributing to the literature of wearable device and tourism. It also aims at providing an insight of the influence of wearable devices on tourists' behavior. The paper provides an overview of wearable device functionalities and presents an insight of used cases in the tourism context.
\end{abstract}

Keywords: wearable device, smart technology, tourism

\section{Introduction}

Information and communication technologies (ICTs) have substantially influenced the tourism industry, and they continue to serve as the main drivers for tourism innovations. We see evidence in literature that ICTs have drastically transformed the way tourism products are developed, presented, and offered (Buhalis, 2003; Buhalis \& Law, 2008). The technological influence in the tourism industry does not only impact the suppliers, but also the consumers. Central to the entire discipline of ICTs adoption in tourism is that the furtherance of ICTs has specifically denoted changes in tourists' behavior. Patently, the great success of ICTs is influencing tourists' attitude towards mobile applications thereby increasing users' experience (Compuware, 2012). Indeed, the wide scope of the involvement of ICTs in tourism has triggered significant discussions among scholars. And it is believed that the transformation of best operations and strategic practices in the tourism industry emerges as a result of internet (Buhalis \& Law, 2008). Certainly, this is because internet facilitates access of information to every corner of the globe. It is inevitable to admit that the application of ICTs in tourism is an important component in the supply chain (Tourism Embassy, 2013).

Evidence points out that, ICTs create more accessibility and enjoyment for both residents and tourists through interactive service and interconnectivity (Buhalis \& Amaranggana, 2014). Another view is that we live in a "smart world" in which its landscape works in a permanent process of evolution and getting friendly due to rapid advancement of ICTs (Blanco, 2011). Undisputedly, the employment of ICTs is providing clearer solutions which are serving towards reduction of spending time and money and on the other hand triggers new tourists’ reactions (Tourism Embassy, 2013; Apichai, 2011).

\footnotetext{
* Acknowledgement: The author gratefully acknowledges Feisal Abdalla for his valuable support. Roland Atembe, Ph.D. student, School of Management, University of Innsbruck. Email: roatembe@yahoo.com.
} 
The world continues to go digital with numerous forms of ICTs, which are being developed on a daily basis. These ICTs have powerful operating systems such as iOS5, Android, and many more which are standard features of modern mobile phones. Indeed, with access to mobile web or "apps", multitudes of new circumstances are being created (Egger, 2013). For instance, wireless and mobile technologies have had a large influence on tourists' behavior in recent years. These technologies allow tourists to perform mobile social web activities hence creating a new way of life (Fesenmaier, Klein, \& Buhalis, 2000; Ye \& Tussyadiah, 2011; Lee \& Mills, 2010; Luz, Anacleto, \& Almeida, 2010; Tourism Review, 2014; Tussyadiah \& Fesenmaier, 2008; Wang, Park, \& Fesenmaier, 2012); and also smoothens the creation of significant personalized experiences (Mihajlovic, 2014; Neuhofer, Buhalis, \& Ladkin, 2015).

Recently, emerging in the discourse of academia and within the tourism industry is that technologies are getting smarter and becoming wearable devices. Although it is relatively new, wearable technological devices are predicted to have a significant effect on people's interaction with surroundings (Tate, 2012) and drastically transform tourists' behavior due to the perceived new ways of interaction with these technologies (Cortland, 2013; Steele, 2014; Tussyadiah, 2014a). However, research describing the application of wearable devices in tourism is relatively lacking in academic literature. This paper thus presents an exciting opportunity to expand research on the implementation of wearable devices in tourism.

The essay first presents the rationale and conceptual background, and then it goes on to discuss the concept of smart technologies and its impacts on tourism. Furthermore, the paper assesses wearable devices and their functionality and presents a Metrix of possible application in tourism. Finally, the paper highlights selected use cases and discusses the implications and suggestions for further research.

\section{Rationale and Conceptual Background}

Previous researchers have found that portable technological devices such as notebook, tablets, and smartphones play a significant role in tourists' experiences (Tussyadiah \& Fesenmaier, 2007; Wang et al., 2012; Tussyadiah, 2013; Green, 2002; Tussyadiah \& Wang, 2014). This is conceivable because currently, personal technologies are associated with one’s everyday life (Gretzel \& Tazim, 2009). Nevertheless, at the present time, the tourism industry is confronted with a set of new challenges resulting from changes in consumers' attitudes and the environment which is influenced by these emerging technologies (Buhalis \& Amaranggana, 2014). In addition to these technological devices getting smaller in size and shape, there are also designs as wearable devices. Indeed, the devices are online web accessible and increasingly interconnected (Wang et al., 2012; Tussyadiah, 2013). This has posed, undoubtedly, an increasing concern that new technologies have the potentials to drastically transform tourists' behavior due to the perceived new ways of interaction with the technologies (Cortland, 2013; Steele, 2014; Tussyadiah, 2014b).

This essay, however, is set in the context of wearable devices. The paper seeks to explore the application of wearable devices in tourism. The study aims at understanding how wearable devices can change the tourists' behavior. It also strives to conceptualize a framework for using wearable technology as smart technology. Notwithstanding, Tussyadiah's (2014a) study concluded that the distinct features and functionalities on wearable technology trigger the shift from tourists to explorers, an explosion of first person visual travel narratives, and more social travel supported by real-time connectivity. This provides the underlying rationale for this study to advance the theoretical framework of the usage of wearable devices for tourism related purposes. As such, a conceptual framework illustrated in Figure 1 has been developed to explore this nascent phenomenon. Building on this rationale, this study aims at contributing to the literature of wearable devices and tourism. 


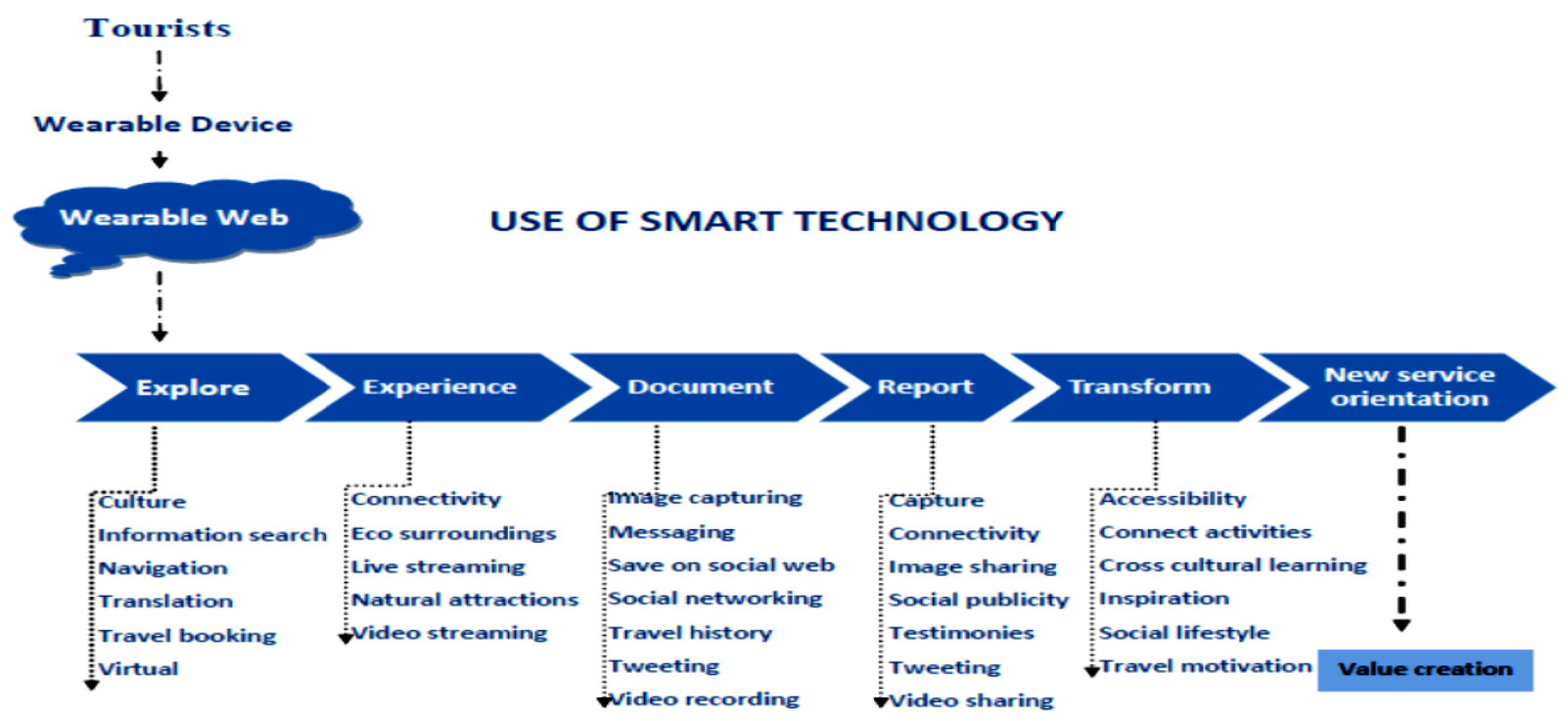

Figure 1. Conceptualizing the use of wearable devices in tourism. Source: Adapted and modified from Tussyadiah (2014a).

\section{Literature Review}

\section{Smart Technology and Tourism}

The term smart technology is the generalization of the concept smart structure. Smart technologies comprise of mechanical systems equipped with sensors, actuators, and pre-programmed controllers which allow a structure to adapt to unpredictable external loading conditions (Holnicki-Szule, Motylewski, \& Kolakowski, 2008). Smart technologies can be seen as a logical progression of ICTs from traditional location-based technologies and more recently mobile technologies. Another view is that smart technology stems from two words "smart and intelligent". It is a term used to describe a product, condition, or motion of a technology that entails a variety of functionalities that can be adapted to certain functions or is tailored to specific circumstances (Worden, Bullough, \& Haywood, 2003). Intelligent systems have been defined as systems with the two fold ability to sense the environment and learn actions to achieve particular objectives. Smart technologies have become pervasive in electronic markets across many areas, including retail and tourism (Alt \& Klein, 2011).

With the rapid advancement of society and industries and the proliferation of ICTs, smart technologies have received predominant interest in the tourism industry. Evidence shows that the concept of "smart" is being applied in tourism. This is because the cities and destinations are becoming increasingly smart (Ronay, 2015; Lopez de Avila, 2015). The increase of smart technologies and wireless connection reduces time and distance limitation which leads to positive communication and relations between suppliers and consumers. Particularly, smart technologies have opened up new space for business opportunities, due to the convergence of the offline and online world (Lee, 2012). In tourism, for instance, smart technologies have served in energy monitoring in hotels (Rogerson \& Sims, 2012); consumers support through the implementation of QR codes; sensors, tags, RFID, and the use of cloud computing in the establishment of smart city (Komninos, 2013). Nevertheless, recent developments in the field of technology reveal that in addition, "smart" technologies are becoming wearable. Thus, the main question which remains unanswered is how these wearable devices are integrated into tourism. For this reason, it is essential to systematically denote how the device can be employed in tourism. 


\section{Wearable Devices and Functionality}

Wearable technology is a term used to describe many different forms of body mounted technology. The Wright Design for Plastic Logic (2014) noted that the term wearable device can cover a number of different products that can all impact the electronic market. In real sense, a wearable device/gadget is technology that the users actively place on the body hands-free. In fact, another description is that wearable technologies are application enabled computing devices which accept and process inputs (Jhajharia, Pal, \& Verma, 2014). The technologies must contain advanced circuitry, wireless connectivity, and at least a minimal level of independent process capability "smart" (Chen \& Shih, 2014). Wearable technologies facilitate a new form of interaction between the human and the computer (Jhajharia et al., 2014). However, in order for a technological device to be called wearable device, it must be worn on the user's body for an extended period of time (Chen \& Shih, 2014). These wearable technologies tend to be more sophisticated than hand-held technologies and the wearable devices actually come in different forms such as smart glasses, smart watches, Bluetooth headsets, smart clothing, etc. (Jhajharia et al., 2014; Chen \& Shih, 2014; Ye, Malu, Oh, \& Findlater, 2014).

Because of the infrared, Bluetooth, or WLAN transmission technologies which are the main catalysts for mobile interaction with the environment (Egger, 2012), these devices can provide sensory and scanning features not typically seen in mobile and laptop devices, such as bio feedback and tracking of physiological function. The portable hands-free wearable device "Google Glass", for example, imbues augmented reality features. The glass is designed in the form of spectacles and it has a tiny computer screen and camera built into one corner of the frames (Tate, 2012). The smart glass illustration in Figure 2 depicts that the glass has four main categories to control input and output of human-computer interaction. These include the visual-based, audio-based, sensor-based, and the touch-based (Dodge \& Kitchin, 2011).

The device is compatible to a smart phone that has Android Version 4.3.0 (ice cream sandwich) or with an apple phone with "IOS7" software (Lendino, 2014). With the aid of this software, an application called "My Glass" can be installed. This app set-up facilitated by internet and Bluetooth connection enables the running and functionality of Google Glass.

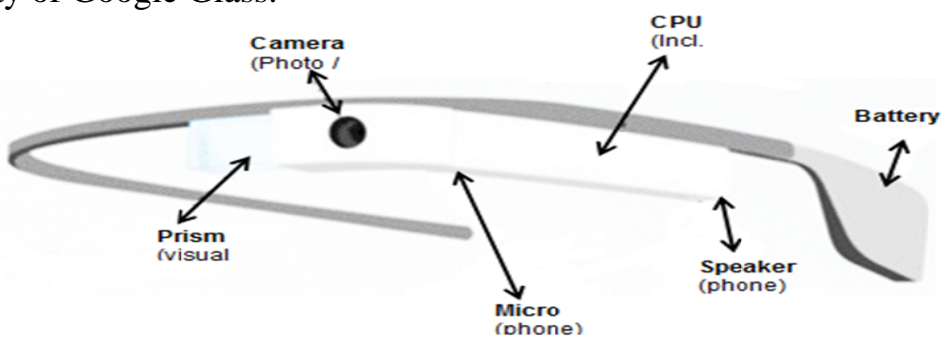

Figure 2. Features of Google Glass. Source: The author (2015).

Google Glass has a processor of TI OMAP 4430 1GB RAM, 802.11 b/g WIFI, GPS, and a capacity of 16 GB of internal storage as well as 12.5 GB free for the user (Lendino, 2014; Google Inc., 2014). The usage of Google Glass is done by voice commands, head tilts, taping the touch pad on the side or head lifts. When this is done, the glass activates its different functionalities such as pictures shooting, video streaming, message sending, getting directions, sharing pictures, etc. (Lendino, 2014). The first version of the device was manufactured in the summer of 2011 and subsequently, it was presented to the public for the first time on April 5, 2012. Since then, the device has gone through a series of software updates. The most current version of the glass is the XE-C with double amount of RAM and other upgrades. Since then, Google Inc. continues to add more applications to the glassware (Widmer \& Muller, 2014). 
The Google Glass has several distinct applications which have different input methods such as voice commands, touchpad, taking pictures, and recording videos (Glass Almanac, 2013). The notion is that Google Glass assists people to experience technology without its interference in their beloved activities (Jordan, 2013). The glass provides the possibility to capture extreme moments of adventure that would normally not be easy to capture using different devices like cameras or smart phones (Mann, 2012). In addition, Google Glass gives users the possibility to post status updates, share images, videos on social media such as Google Plus, Facebook, and Twitter. Certainly, glass users obtain timely notifications and direct messages (Widmer \& Muller, 2014). It is considered to be significant for the dissemination of helpful information to users about their surroundings. However, this functionality of Google Glass is closely related to location-based services (Glass Almanac, 2013). The wearable technologies that are currently in the forefront of most consumers' minds are the smart watches. The technology has done well in highlighting the potential of wearable electronic devices since it was launched on November 7, 2014 (Wright Design for Plastic Logic, 2014).

\section{Application of Wearable Devices in Tourism}

Wearable technology is one of the popular emerging trends in 2014 Consumer Electronic Shows. Although Chen and Shih (2014) claimed that wearable technology is not a brand new technology, it should be noted that we are gearing towards the post-smartphone era where personal technological devices are being transformed to wearable gargets. Thus, wearable technologies are regarded as important secret weapons in the exploitation of smart phones. These technologies add some functions to create innovative and diverse services or goods for offering people a better quality of life. As with other technologies that have come in the past, the trial of possible application of wearable devices in tourism has been evidently reported. The matrix illustrated in Table 1 gives an overview of the possible applications of wearable devices in the tourism context.

Table 1

Matrix of Possible Applications of Wearable Devices in Tourism

\begin{tabular}{|c|c|c|c|}
\hline $\begin{array}{l}\text { Type of wearable } \\
\text { devices }\end{array}$ & Possible application in tourism & Tourism segment trialed & Source \\
\hline Smart watch & $\begin{array}{l}\text { Efficient messaging: rich notification such as status } \\
\text { updates, comments, photo tags, check-ins, and data }\end{array}$ & Destinations & Conyette (2015) \\
\hline Bracelets/watches & $\begin{array}{l}\text { Tracking of guests' sleeping patterns: clients wear a } \\
\text { watch while sleeping as it can track their sleeping patterns } \\
\text { and wake them through gentle vibrations }\end{array}$ & $\begin{array}{l}\text { Accommodation: } \\
\text { Western Hotels }\end{array}$ & Harkness (2015) \\
\hline Wrist band & Wrist band swipe hotel room keys & $\begin{array}{l}\text { Accommodation: } \\
\text { Disney Resorts } \\
\text { Cruise lines: } \\
\text { Caribbean Cruise Lines } \\
\end{array}$ & Joyce (2013) \\
\hline Smart glasses & $\begin{array}{l}\text { Tourists use museum smart glass prototype to see cultural } \\
\text { artifacts at the museum and also activate digital contents } \\
\text { such as video, games, photos, etc. on the glass display } \\
\text { screen by simply looking at the collection item }\end{array}$ & $\begin{array}{l}\text { Museums: } \\
\text { Royal Ontario } \\
\text { Museum's Ming Tomb }\end{array}$ & Emrich (2015) \\
\hline Smart glasses & $\begin{array}{l}\text { Look through lens: arts gallery and museum visitors are } \\
\text { able to easily switch between real objects and augmented } \\
\text { reality }\end{array}$ & $\begin{array}{l}\text { Theme parks, zoos, and } \\
\text { aquariums }\end{array}$ & $\begin{array}{l}\text { Wear Geared Inc. (2015) } \\
\text { Conyette (2015) }\end{array}$ \\
\hline Smart watches & $\begin{array}{l}\text { Travelers with android devices can integrate travel } \\
\text { management itinerary app, which allows the traveler to } \\
\text { click on notification on the watch. Tourists can also } \\
\text { receive real-time flight alerts, gate changes, and other } \\
\text { information on their wrists through an app called } \\
\text { TripCase }\end{array}$ & $\begin{array}{l}\text { Airports and travel } \\
\text { agencies: Sabre }\end{array}$ & $\begin{array}{l}\text { Conyette (2015) } \\
\text { Sabre Inc. (2015) }\end{array}$ \\
\hline
\end{tabular}

Note. Source: The author (2015). 


\section{Emergence of Wearable Devices in Tourism}

As the demands of consumers are currently increasing, many companies are constantly striving for new strategies to satisfy their customers. Certainly, this is because customer satisfaction is the core determinant for the success of every business. The tourism industry is a service-intensive sector; thus, tourism-related companies are always employing new strategies to meet the needs and demands of the tourists (Safak, Allison, \& Sheremet, 2003). The convergence of portable technological devices and internet connectivity enables tourists to consume media content universally at whatever chosen times (Sundet, 2012). In this light, tourism practitioners are constantly employing the use of ICTs to their advantage. Indeed, evidence can be seen from the use cases of wearable technology "Google Glass” being applied in travel and tourism. As presented in the matrix above, wearable devices offer high functionalities that can be anticipated in tourism and have been trialed. Nevertheless, the focus below is built on some selected cases of use in various segments of tourism.

Use case: Air travel. The nature of air travel industry is associated with a high level of processes between passengers and the airlines (Egger, 2012). In order to cope with these challenges, the airlines companies are required to adopt alternative approaches to manage the traffic flow of their customers. Several use cases of Google Glass in the aviation sector have been noticed within its explorer programme. The Virgin Atlantic Airlines staff at Heathrow Airport, London, has used the Google Glass to provide the best services to their customers in early 2014. The glass enables Virgin Atlantic Airlines to offer timely information regarding local weather and language translations to their customers (Suleman, 2014; Clark, 2014).

Similarly, Copenhagen Airport has also adopted the use of Google Glass for its operations. The wearable device helps passengers' questions relating to their airport journey, reducing passenger queue up at the customer service desk. Indeed, the smart glass also enables the reporting of common use of the airport facilities. For instance, the glass is used to document the state of the departure gate area via photos and videos after the use of every airline's staff. Thus, it facilitates accountability of untidy work stations at the airport (Ghee, 2015). Furthermore, the Copenhagen Airport's staffs report that the use of Google Glass enables them to reduce paper work, thus increasing efficiency in language translations. It also provides availing information such as gates, baggage, and flight to customers. The use of Google Glass at airports eases the stress of travelers and provides information about flight running late, traffic delays on the way to the airport, location of luggage, and check-in gates (Travel Mail Reporter, 2014).

Another use case of Google Glass within the aviation sector can be exemplified in Spring Airlines, a Chinese-based low-cost carrier (Spring Airlines), which is the first to use glass on board to improve customer services. The airlines' flights attendants are empowered with Google Glass to help them identify specific passengers who had placed orders for food and beverages. Furthermore, the Edinburgh Airport is reported to be the second UK airport to embrace wearable technology. The glass facilitates and provides passengers with real-time flight information, helps translate foreign language documents, and facilitates responses to general questions about the airport (Future Travel Experience, 2014). Several great benefits offered by Google Glass have been identified by the airlines and airports and there is more potential usage in other areas such as operations, customer services, security, and immigration in the air transport industry (Ghee, 2015). 
Use case: Lodging services. The hospitality industry is another sector adopting and making use of the Google Glass. The Starwood Hotels' pilot programme that was initially introduced to allow guests to swap physical keys for virtual keys facilitating guests to use their smartphones has been flash forward. Starwood Hotels has implemented the Starwood Preferred Guest (SPG) app for Google Glass (Nelson, 2014). Starwood Hotels' SPG app empowers guests to get directions to the hotel and explore and share the image of the hotel with friends. In addition, guests are able to access their room reservations, star point balances, and upcoming events (Moscaritolo, 2014).

Other examples of use case of Google Glass in the hospitality industry can be seen in ACME Hotel. Travelers who are curious about Google Glass have the possibility to experience it at the hotel. The guests are given the opportunity to rent Google Glass complementarily for duration of three hours to explore their surroundings (Coyle, 2014).

Use case: Consumers' travel guide. As with other portable devices, Google Glass can elucidate tourist experiences. It enables tourists to multi task through the provision, and alleviates limitation of access to experiences. While exploring destination tourists can respond to messages, get local travel maps and other required information while driving. In fact, as Fowler (2015) noted, personal technologies are intermediaries between the users and artefacts. Technologies appear in humans and the world and it changes human experiences (Ihde, 1990). Based on the multiplicity of apps and features in Google Glass that allows the possibility for tourists to experience technology without its interference in their beloved activities (Jordan, 2013), it is reasonable enough to consider that the glass can be used for tourism experiences. These include cognitive activities such exploring environments, retrieving information, taking pictures and videos, and sharing their overall experiences at a destination. Ultimately, Google Glass serves as a travel guide for tourists. The interactive and context-oriented travel guides tell users what they need to know about the area around them (Humma, 2013). The guide can be used completely offline with the help of GPS which triggers audio clips to play automatically as the tourists get closer to the various points of interest in the destination.

\section{Discussion}

Wearable devices' acceptance and usage in the tourism sector appear to be showing an increased interest. It is clear that the speculations made about the application of wearable devices in tourism are evidently surfacing. The hospitality sector of the tourism industry has always been associated with highly intensive labor demand, which often results in long working hours, long waiting times for the clients, etc.. Certainly, with these emerging wearable technological devices, the services rendered to customers will be expedited. Wearable devices provide guests with smarter solutions. The automated check-in at the front desk, voice command keys for room access, ability to access account folios updates to include details on any upcoming stay, as well as accumulated points for the hotel guest loyalty programme will ease the work and provide guests with better service quality. In addition, guests can also control their spending patterns since they can actively track down their folios without contacting the management. While on the supplier side, it is expected that high level of efficiency of processes and service delivery procedures will be attained and synergy effects will be reached. However, as with other technologies, organizations are often confronted with the task of evaluating the cost of investments and the benefits the technology would bring to the organization. The hospitality sector is very competitive and customers' demand for valuable experience is increasing constantly. Therefore, taking advantage of such technology will boost business output and also elucidate customer experience. Nevertheless, 
one challenge that should be taken into consideration is the level of cost effectiveness for tourism organizations in the adoption of wearable devices for use in their operations or service deliveries, especially the small- and medium-sized enterprises.

Attractions have gained new lives, because over the last years, the demographic shift in tourism has affected most traditional tourist attractions such as museums. According to Conyette (2015) and the National Endowment for the Arts (n.d.), there has been a significant decline in the participation of museums and arts galleries by the younger generation aged between 18 and 24 years old. This is because of the competition for audiences between fine arts, video games, movies, and other entertainments within the diverse populations in Europe and USA.

Arts galleries and museums are precious institutions and heritage centers. Therefore, employing wearable devices could give new life to museums and galleries through the application of self-voice command audio guide in an interactive and modern manner. The use of wearable devices in this context could be for access control, ticking, information, and audio tour guide.

In the transportation sector, wearable devices show high potentials towards speedy processes. Most passengers are always in the rush to board the flight and be seated for departure. That is the reason why most airlines have taken advantage of smart technologies by introducing mobile boarding passes and mobile check-ins respectively, where clients use their cell phones. But definitely, wearable devices are changing the role of the game. As more airlines adopt wearable devices for flight boarding, check-in, and luggage tracking, security and privacy concerns become another threat and a call for concern. Evidence predicts that airports authorities will most probably employ wearable devices for security screening for both passengers and luggage.

\section{Conclusion}

This study was set out to depict the usage of wearable technological devices in tourism. Evidence points out that the usage of wearable devices paves the way to revolutionize the tourism industry, thus creating added value for both suppliers and consumers. It can be seen that wearable devices have shifted internet from the mobile cyber space to become wearable on the body. With this wearable web, tourists are able to obtain required information, communicate, share experiences, resolve several setbacks encountered when traveling, and co-create their own value without any physical activity. This study further affirms that wearable devices will transform consumers from tourists to explorers. In addition to time, place, context, and personalization to tourists' offers and experiences, the wearable web will certainly empower tourists to re-construct their experiences. This means that with a voice command, tourists can programme a series of activities or actions for a given period of time and at a specific location without requiring assistance from the tourism supplier. Therefore, with the emergence of wearable devices, the trend indicates a further disintermediation whereby tourists will be taking an upper hand on the entire service delivery process. As a result, the new face of tourism will be focused on the optimization of "personalized re-constructed experiences" by the consumers. Indeed, a wide range of possible applications of wearable devices opens up for the tourism industry, from both the suppliers and the consumers' sides. It is, however, anticipated that due to the interactivity, intimacy, and ubiquity of wearable devices, tourism suppliers will exploit the nature of such devices and denote opportunities to provide customized, enhanced, automated, and new experiences for tourists. But, the main challenge to be considered is privacy and security. The usage of wearable devices in tourism poses serious concerns with regard to privacy and security. Since tourists can "voice command" check-in and access up-to-date information about their accounts in a hotel, for instance, it means that they have access to the data portal of the hotel. Therefore, they might possibly be tempted to access unauthorized data of the establishment to satisfy their curiosity as explorers. 
With regard to strategic recommendations, it should be noted that wearable devices are fast developing technologies that will showcase a continuously significant impact on tourists and tourism organizations. And with the internet of things, it is certain that tourism suppliers should begin to streamline their current business models and strategies in order to benchmark with competitors and to cope with the challenges that will be faced in meeting the tourists' demands.

Although this paper contributes by highlighting the usage of wearable devices in tourism and the potentials for the future, there were several limitations. First, the literature on wearable devices and tourism is very nascent. Therefore, in this paper, most sources about wearable devices usage in tourism were non-academic sources. In any case, there is a potential for exploration of this valuable area of research. As such, this paper serves as the first valuable step towards a clear understanding of the application of wearable devices in tourism. A further study is recommended to explore the value creation of wearable devices in tourism. It is also suggested that a deeper examination should be carried out to uncover the economic impacts of wearable devices in this industry.

\section{References}

Alt, R., \& Klein, S. (2011). Twenty years of electronic markets research—Looking backwards towards the future. Electronic Markets, 21(1), 41-51.

Apichai, S. (2011). How technology is changing global tourism. In Technology in tourism (Vol. 1). UNWTO Affiliate Members, AM Reports.

Blanco, J. (2011). Understanding and managing innovation and technological change: A major opportunity for tourism organizations. In Technology in tourism (Vol. 1). UNWTO Affiliate Members, AM Reports.

Buhalis, D. (2003). eTourism: Information technology for strategic tourism management. London, UK: Pearson (Financial Times/Prentice Hall).

Buhalis, D., \& Amaranggana, A. (2014). Smart tourism destinations. In Z. Xiang, \& I. Tussyadiah (Eds.), Information and communication technologies in tourism 2014 (pp. 553-564). Switzerland: Springer International Publishing.

Buhalis, D., \& Law, R. (2008). Progress in information technology and tourism management: 20 years on and 10 years after the Internet-The state of eTourism research. Tourism Management, 29(4), 609-623.

Chen, C. C., \& Shih, H. S. (2014). A study of the acceptance of wearable technology for consumers: An analytical network process perspective. International Journal of the Analytic Hierarchy Process.

Clark, N. (2014). Airlines use digital technology to get even more personal. Retrieved from http://www.nytimes.com

Compuware. (2012). Mobile apps: What consumers really need and want. A global study of consumer's expectations and experiences of mobile applications. Compuware, the Technology Performance Company. Retrieved from https://info.dynatrace.com/rs/compuware/images/Mobile_App_Survey_Report.pdf

Conyette, M. (2015). 21st century travel using websites, mobile and wearable technology devices. Athens: ATINER's conferences Paper Series, No. TOU2015-1475.

Cortland, S. (2013). Google glasses. Retrieved from https://sites.google.com/a/cortland.edu/google-glasses/disadvantages

Coyle, P. (2014). Cities, hotels, destinations eye Google Glass to promote tourism. Retrieved from http://www.livability.com/topics/business-and-economy/cities-hotels-destinations-eye-google-glass-promote-tourism

Dodge, M., \& Kitchin, R. (2011). Code and space: Software and everyday life. Cambridge, MA: MIT Press.

Egger, R. (2013). The impact of near field communication on tourism. Journal of Hospitality and Tourism Technology, 4(2), 119-133.

Emrich, T. (2015). Disrupting art with wearable technology. Retrieved from http://betakit.com/disrupting-art-with-wearable-technology/

Fesenmaier, D. R., Klein, S., \& Buhalis, D. (Eds.). (2000). Information and communication technologies in tourism. Springer.

Fowler, A. G. (2015). Sling TV: A giant step from cable. The Wall Street Journal.

Future Travel Experience. (2014). Virgin Atlantic launches industry's first wearable technology trial at London Heathrow - Airline to exclusively discuss findings and lessons learned at FTE Europe 2014 . Retrieved from http://www.futuretravelexperience.com/2014/02/virgin-atlantic-launches-industrys-first-wearable-technology-trial-london-heat hrow-airline-exclusively-discuss-findings-lessons-learned-fte-europe-2014/ 
Ghee, R. (2015). Google Glass still has "huge potential” for airlines and airports despite Google ending sales of the product. Future Travel Experience.

Glass Almanac. (2013). The history of Google Glass. Retrieved from http://glassalmanac.com/history-google-glass/5

Green, N. (2002). On the move: Technology, mobility, and the mediation of social time and space. The Information Society, 18(4), 281-292.

Gretzel, U., \& Tazim, J. (2009). Conceptualizing the creative tourist class: Technology, mobility and tourism experiences. Tourism Analysis, 14(4), 471-481.

Harkness, S. (2015). Wearable and wanderlust: How technology is changing travel. Retrieved from http://www.screenpilot.com/2015/03/wearables-wanderlust-how-technology-is-changing-travel/

Holnicki-Szule, J., Motylewski, J., \& Kolakowski, P. (2008). Smart technologies for safety engineering. John Wiley \& Sons, Ltd..

Humma, J. (2013). You walk, while we talk: Tourism radio. Retrieved from https://www.youtube.com/watch?v=yqADdvYbhL0

Ihde, D. (1990). Technology and the lifeworld: From garden to earth. Bloomington, IN: Indiana University Press.

Jhajharia, S., Pal, S. K., \& Verma, S. (2014). Wearable computing and its application. International Journal of Computer Science and Information Technologies, 5(4), 5700-5704.

Jordan, T. (2013). Google I/O 2013: Developing for glass. Retrieved from https://www.youtube.com/watch?v=UK8Ho4p3bZc

Joyce, S. (2013). A brief history of travel technology - From its evolution to looking at the future. Retrieved from http://www.tnooz.com/article/a-brief-history-of-travel-technology-from-its-evolution-to-looking-at-the-future/

Komninos, N. (2013). Smart cities and the future internet: Innovation ecosystems of embedded spatial intelligence. Paper presented at the ICEIRD 2013 Conference.

Lee, H. J. (2012). A review of value creating motive and business model in smart technology. In Y. H. Park, Q. Jin, M. S. Yeo, \& B. Hu (Eds.), Human centric technology and service in smart space (Vol. 182, pp. 159-163). Dordrecht: Springer Verlag.

Lee, J. K., \& Mills, J. E. (2010). Exploring tourist satisfaction with mobile experience technology. International Management Review, 6(1), 91-111.

Lendino, J. (2014). Google Glass: Everything you need to know. Retrieved from http://www.pcmag.com/article2/0,2817,2416488,00.asp

Lopez de Avila, A. (2015). Smart destinations: XXI century tourism. Presented at the ENTER2015 Conference on Information and Communication Technologies in Tourism, Lugano, Switzerland, February 4-6, 2015.

Luz, N., Anacleto, R., \& Almeida, A. (2010). Tourism mobile and recommendation systems - A state of the art. Paper presented at the International Conference on E-Learning, E-Business, Enterprise Information Systems, \& E-Government, Las Vegas, Nevada.

Mann, S. (2012). Eye am a camera: Surveillance and sousveillance in the glassage. Time Magazine.

Mihajlovic, I. (2014). ICT and new trends in consumer behavior - New experiential knowledge, opportunities or challenges for intermediaries. Journal of Marketing Management, 2(1), 43-64.

Moscaritolo, A. (2014). Use Google Glass app to book Starwood Hotel rooms. Retrieved from http://www.pcmag.com/article2/0,2817,2456681,00.asp

National Endowment for the Arts. (n.d.). Retrieved from http://arts.gov/sites/default/files/nea-history-1965-2008.pdf

Nelson, R. (2014). Starwood hotels welcome Google Glass with SPG glassware. Retrieved from http://androidcommunity.com/starwood-hotels-welcome-google-glass-with-spg-glassware-20140416

Neuhofer, B., Buhalis, D., \& Ladkin, A. (2015). Smart technologies for personalized experiences: A case study in the hospitality domain. Electronic Markets, 25(3), 243-254.

Rogerson, J. M., \& Sims, S. R. (2012). The greening of urban hotels in South Africa: Evidence from Gauteng. Urban Forum, 23(3), 391-407.

Ronay, E. (2015). A scenario technique application to implement smart concept in tourism destination. Paper presented at the International Student Conference in Tourism Research "ISCONTOUR".

Sabre. (2015). Access your travel data from wherever you are: Tripecase travel app. Retrieved from http://www.sabre.com/our-technologies/mobile

Safak, I., Allison, M. A., \& Sheremet, A. (2013). Floc variability under changing turbulent stresses and sediment availability on a wave energetic muddy shelf. Continent Shelf Research, 53, 1-10.

Steele, C. (2014). Should you buy Google Glass? Retrieved from http://www.pcmag.com/article2/0,2817,2456442,00.asp

Suleman, K. (2014). Virgin Atlantic hails Google Glass trial a success. Retrieved from http://www.itpro.co.uk/mobile/22098/virgin-atlantic-hails-google-glass-trial-a-success 
Sundet, V. S. (2012). Making sense of mobile media: Institutional working notions, strategies and actions in convergent media markets (Ph.D. thesis, University of Oslo).

Tate, A. (2012). Google glasses (Project glass): The future of human computer interaction? Retrieved from http://usabilitygeek.com/google-glasses-project-glass-the-future-of-human-computer-interaction/

Tourism Embassy. (2013). The use of new technologies in the tourism industry. Retrieved from http://tourismembassy.com/en/blog/tourism-trends/the-use-of-new-technologies-in-the-tourism-industry

Tourism Review. (2014). Technology update: Mobile travel consumers' trends. Retrieved from http://www.tourism-review.com/mobile-travel-consumers-trends-news4124

Travel Mail Reporter. (2014). Flying into the future: Copenhagen becomes first airport to trail staff use of Google Glass. Retrieved from http://www.dailymail.co.uk

Tussyadiah, I. (2013). When cell phones become travel buddies: Social attribution to mobile phones in travel. In L. Cantoni, \& Z. Xiang (Eds.), Information and communication technologies in tourism 2013 (pp. 82-93). Berlin-Heidelberg: Springer-Verlag.

Tussyadiah, I. P. (2014a). Expectation of travel experiences with wearable computing devices. In Z. Xiang, \& I. Tussyadiah, (Eds.), Information and communication technologies in tourism 2014 (pp. 539-552). Switzerland: Springer International Publishing.

Tussyadiah, I. P. (2014b). Toward a theoretical foundation for experience design in tourism. Journal of Travel Research, 53(5), 543-564.

Tussyadiah, I. P., \& Fesenmaier, D. R. (2008). Marketing places through first-person stories - An analysis of Pennsylvania roadtripper blog. Journal of Travel \& Tourism marketing, 25(3-4), 299-311.

Tussyadiah, I. P., \& Wang, D. (2014). Tourists' attitudes toward proactive smartphone systems. Journal of Travel Research, 1-16.

Tussyadiah, I., \& Fesenmaier, D. (2007). Interpreting tourist experiences from first-person stories: A foundation for mobile guides. Proceedings of the ECIS 2007, Paper 104. Retrieved from http://aisel.aisnet.org/ecis2007/104

Wang, D., Park, S., \& Fesenmaier, D. R. (2012). The role of smartphones in mediating the touristic experience. Journal of Travel Research, 51(4), 371-387.

Wear Geared Inc. (2015). Products. Retrieved from http://weargeared.com/index.shtml

Widmer, A., \& Muller, H. (2014). Using Google Glass to enhance pre-hospital care. University of Applied Sciences Western Switzerland (HES-SO).

Worden, K., Bullough, W. A., \& Haywood, J. (2003). The smart approach - An introduction to smart technologies. In K. Worden, W. A. Bullough, \& J. Haywood (Eds.), Smart technologies. River Edge: World Scientific.

Wright Design for Plastic Logic. (2014). Flexible displays for wearable technologies. Retrieved from http://www.plasticlogic.com/markets/wearables/

Ye, H., \& Tussyadiah, I. P. (2011). Destination visual image and expectation of experiences. Journal of Travel \& Tourism Marketing, 28(2), 129-144.

Ye, H., Malu, M., Oh, U., \& Findlater, L. (2014). Current and future mobile and wearable device use by people with visual impairments. Association for Computing Machinery, Toronto, Ontario, Canada. 